\title{
JUURNAL_RU
}

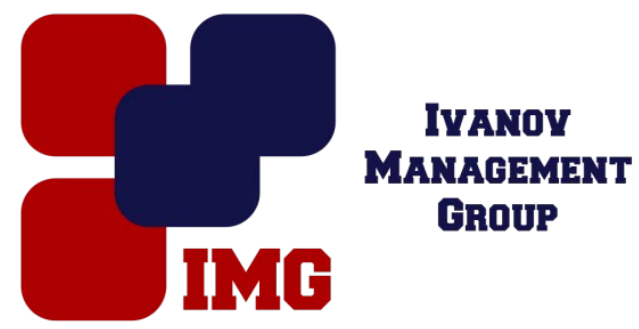

Шапошников В.И. НОЧУ ВО Кубанский медицинский институт Краснодар, Россия

doi: 10.18411/lj-31-01-2017-3-02

idsp 000001:lj-31-01-2017-3-02

\section{Значение интернет в медицинском вузе}

Вопросы улучшения образовательного процесса ещё остаются актуальными в России. До последнего времени студенты медицинских учебных заведений базовую информацию по различным проблемам здравоохранения в основном получали из учебника по той или иной дисциплине. В лекциях приводились дополнительные сведения о достижениях, которые медицинская наука достигла за последнее время. На это были нацелены и методические рекомендации. На практических занятиях со студентами эти знания закреплялись у них у постели больного, в операционных, перевязочных и в различных кабинетах и лабораториях.

Это было до тех пор, пока в учебный процесс не стали активно внедряться электронные технологии. Практически любые данные по учебной программе студенты могут найти в Интернете. Они быстро оценили этот способ мгновенной информации, и стали использовать его не только для подготовки к занятиям, но и в качестве своеобразной шпаргалки, а это заметно снизило у них логическое мышление, а заодно и память. Они перестали надёжно запоминать симптомы заболевания, методы диагностики и лечения и все остальные конкретные знания, которыми так богата медицина, надеясь на подсказку электронных носителей, особенно планшетов.

Личная преподавательская деятельность свидетельствует о том, что ныне при сдаче зачета, а тем более экзаменов, студент любые дополнительные вопросы, в которых преподаватель спрашивает об азбучных истинах, но их нет в информации, полученной через Интернет, воспринимает неадекватно. Они его раздражают и ставят в тупик, хотя они и не выходят за рамки учебной программы. Многие из них не могут логически выдержано построить ответ. Не знают и не понимают, почему появляются и развиваются различные симптомы заболевания и так далее.

Возникает законный вопрос, сможет ли этот студент с таким багажом знаний в дальнейшем успешно трудиться врачом в практическом 
здравоохранении, то есть выполнять свой врачебный долг? Вряд ли! Об этом свидетельствует рост врачебных ошибок, который наблюдается в последнее время.

Определенную негативную роль играют и различные ограничения в допуске студентов в операционную, реанимацию и палаты интенсивной терапии, а порой просто в лечебное учреждение. Этот запрет как бы преследует благие цели - сохранение санэпидрежима, но он и затрудняет процесс превращения студента в эскулапа, ведь в процессе учебы он не контактирует с наиболее тяжелыми пациентами, что имеет исключительно важное значение в формировании у него чувства врачебного долга. Контакт же с тяжелобольными вырабатывает у него упорство в спасении жизни больного человека. А без него никогда не стать хорошим врачом.

Очень правильным было бы определять рейтинг каждого вуза, учитывая число хороших специалистов, из общего числа бывших студентов, которые сформировались через пять лет после его окончания. Это усилило бы ответственность преподавателей за качество оказываемых ими образовательных услуг, а заодно и способствовало бы рациональному подбору абитуриентов.

Выводы. В настоящее время надо учитывать Интернет в процессе медицинского образования, чтобы он не мешал, а наоборот помогал в этом архиважном государственном мероприятии. 